\title{
BURZYŃSKI'S CRITERION IN THE ANALYSIS OF HEAT RESISTANT STEEL
}

\author{
Dudda Waldemar* \\ Faculty of Technical Sciences, University of Warmia and Mazury, Olsztyn, Poland, \\ ORCID 0000-0003-4083-9479 \\ *Corresponding author: e-mail: dudda@uwm.edu.pl

\begin{tabular}{|c|c|}
\hline ARTICLE INFO & ABSTRACT \\
\hline $\begin{array}{l}\text { Article history: } \\
\text { Received: August } 2020 \\
\text { Received in the revised form: } \\
\text { September } 2020 \\
\text { Accepted: September } 2020\end{array}$ & \multirow{2}{*}{$\begin{array}{l}\text { A revalorised Burzyński's hypothesis was suggested for determination } \\
\text { of effort of construction elements in thermally variable load conditions } \\
\text { Using the suggested hypothesis, surfaces of the beginning of plasticity } \\
\text { for the heat resistant St12T steel were determined. Two numerical sim } \\
\text { ulations of thermo-mechanical loads of the turbine vane made of St12T } \\
\text { steel were performed. The result of analyses was determination of the } \\
\text { effort states of a vane acc. to Huber-Mises- Hencky's hypotheis and } \\
\text { according to the suggested revalorised Burzyński's hypothesis. }\end{array}$} \\
\hline $\begin{array}{l}\text { Key words: } \\
\text { Burzyński's hypothesis, } \\
\text { equivalent stress, } \\
\text { turbine vane }\end{array}$ & \\
\hline
\end{tabular}

\section{Introduction}

Works concerning materials, especially alloy steel that includes $9-12 \%$ of $\mathrm{Cr}$ have been conducted for many years in the aspect of using these studies in some of steam and gas turbines (Lecomte-Beckers, 2002). Some of these studies reach back to the forties of the last century. Unfortunately, even greater present participation of renewable energy sources enforces a bigger elasticity of the power share from traditional (professional) power stations, which translates into more frequent cycles of start-up and shut-downs and operation of energy blocks with supercritical parameters at which e.g. temperature of the steam overheated in the circumference of the power station may reach even $610^{\circ} \mathrm{C}$. Thermal loads, to which construction materials in the sector of traditional energy are exposed, result the most often (Dudda et al., 2019) from high temperature of fresh steam and secondarily overheated steam, uneven heating during the turbine start, blocking of thermal deformation in connections, thermal cycles during a start-up and shut-down and cycle material loading (Dudda, 2007). Coexistence of high parameters of turbine operation with uneven heating during the start-up, blocking of free thermal deformations in connections etc. may lead to the critical effort of elements of these turbines. Thus, better materials have been searched for particular structural elements such as rotors of turbines, blades, pipelines, boilers, etc.

The paper presents a modified Burzyński's hypothesis for description of the effort of structural elements which may work in thermally variable load conditions (Burzyński, 2008, Banaś and Badur, 2017). For modification of the hypothesis, parameters obtained from experiments of loading the cylindrically shaped samples are used (Dudda, 2019) and applied in numerical simulations. Based on the suggested hypothesis, surfaces of the beginning of yield 
for St12T steel designed for elements of turbines to work in elevated temperatures were determined. Two numerical simulations of thermo-mechanical loads of the turbine vane made of St12T steel were performed. As a result of analyses, the effort states of a vane acc. to Huber-Mises- Hencky's hypothesis and acc. to the suggested Burzyński's hypothesis adjusted to thermal loads were determined.

\section{Reduced stresses}

A considerable majority of computer systems designed, inter alia, for strength analyses of the structure, uses the reduced stress (equivalent, substitutive) resulting from HuberMises- Hencky's hypothesis (HMH). These equivalent stresses for the space system express with the following relations

$$
\sigma_{H M H}=\sqrt{\frac{1}{2}\left[\left(\sigma_{x}-\sigma_{y}\right)^{2}+\left(\sigma_{y}-\sigma_{z}\right)^{2}+\left(\sigma_{z}-\sigma_{x}\right)^{2}\right]+3\left(\tau_{x y}^{2}+\tau_{y z}^{2}+\tau_{z x}^{2}\right)}
$$

or

$$
\sigma_{H M H}=\sqrt{3 J_{2 s}}
$$

where:

$J_{2 s} \quad-$ it is the second invariant of the stress deviator

$\sigma_{x}, \sigma_{y}, \sigma_{z}, \tau_{x y}, \tau_{y z}, \tau_{z x}$ - are normal elements and tangents of stress tensor

We know that there is a considerable group of materials for which corresponding properties have various values depending on the manner of simple loading e.g. various values of tensile strength, compressive strength, twisting strength or various values of the yield strength in these simple effort states. Indicating various properties of the same material at stretching and compression, Burzyński generalized Huber-Mises- Hencky's hypothesis from which the following relation to equivalent stress results:

$$
\frac{\sigma_{B}=\frac{1}{2 \varkappa}\left[(1-\varkappa)\left(\sigma_{x}+\sigma_{y}+\sigma_{z}\right)+\right.}{\left.\sqrt{(\varkappa-1)^{2}\left(\sigma_{x}+\sigma_{y}+\sigma_{z}\right)^{2}+4 \varkappa\left[\sigma_{x}^{2}+\sigma_{y}^{2}+\sigma_{z}^{2}-\sigma_{x} \sigma_{y}-\sigma_{y} \sigma_{z}-\sigma_{z} \sigma_{x}+3\left(\tau_{x y}^{2}+\tau_{y z}^{2}+\tau_{z x}^{2}\right)\right]}\right]},
$$

which may be written down with an equation after simplification:

$$
\sigma_{B}=\frac{1}{2 \varkappa}\left[3(\varkappa-1) \sigma_{m}+\sqrt{9(\varkappa-1)^{2} \sigma_{m}^{2}+4 \varkappa \sigma_{H M H}^{2}}\right]
$$

where:

$\sigma_{m}-$ is an average normal stress according to the relation

$$
\sigma_{m}=\frac{1}{3}\left(\sigma_{x}+\sigma_{y}+\sigma_{z}\right)
$$


- is a coefficient of asymmetry of the elastic region determined with the equation

$$
\varkappa=\frac{R_{e c}}{R_{e r}}
$$

In the above equation (6) $R_{e r}$ means a strength yield at stretching and $R_{e c}$ stands for the strength yield at compression. These values should be determined from the material tests such as static tensile test and static compression test (Banaszkiewicz and Dudda, 2018).

\section{Modification of burzyński's hypothesis}

Numerical analyses of some of the thermo-mechanically loaded parts, such as turbine vanes, should be based on the values of material parameters that depend on the temperature. Thus, in order to apply Burzyński's hypothesis for description of the thermo-mechanical effort of material, it does not suffice to make such properties of materials like Young module $E=E(T)$, tensile strength $R_{m}=R_{m}(T)$ etc. dependent on the temperature. First, the coefficient introduced by Burzyński, for which we now extend the name into temperature coefficient of asymmetry of the elastic region determined with the equation should be made dependent upon the temperature

$$
\varkappa_{T}=\varkappa(T)=\frac{R_{e c}^{T}}{R_{e r}^{T}} \equiv \frac{R_{0.2 c}^{T}}{R_{0.2 r}^{T}}
$$

Therefore, it is indispensable to determine by an experiment the impact of temperature on the values of clear yield strength both to $R_{e r}^{T}$ stretching and compression $R_{e c}^{T}$ and in case of their absence on the values of their contractual counterparts, namely contractual yield strength to stretching and compression determined correspondingly $R_{0.2 r}^{T}$ and $R_{0.2 c}^{T}$ (Banaszkiewicz and Dudda, 2018, Banaszkiewicz et al., 2019).

\section{The impact of temperature on the properties of material}

A vane analysed in the paper is made of St12T steel. To obtain material properties of St12T steel indispensable in the thermo-mechanical analysis, static tests of stretching and compression were performed: each three tests in temperatures of $20,200,400,600^{\circ} \mathrm{C}$ and each one in the temperature of $800^{\circ} \mathrm{C}$ with the use of samples the dimensions of which were presented in figure 1 .

a)

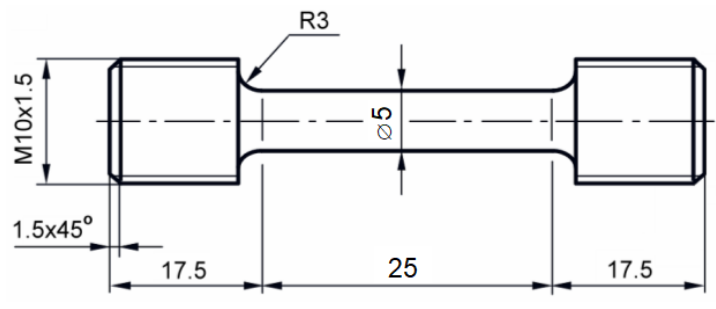

b)

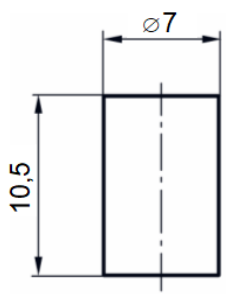

Figure 1. Dimensions of samples for static attempt of stretching (a) and compression (b) 
The average values of the determined properties of St12T steel were placed in Table 1 (Dudda et al., 2019, Dudda, 2019, Dudda, 2020).

Table 1.

Properties of steel St12T in raised temperatures

\begin{tabular}{lcccc}
\hline $\begin{array}{l}\text { Temperature } \\
(\mathrm{T})\end{array}$ & $\begin{array}{c}E(T) \\
(\mathrm{GPa})\end{array}$ & $\begin{array}{c}R_{m}(T) \\
(\mathrm{MPa})\end{array}$ & $\begin{array}{c}R_{0.2 r}^{T} \\
(\mathrm{MPa})\end{array}$ & $\begin{array}{c}R_{0.2 c}^{T} \\
(\mathrm{MPa})\end{array}$ \\
\hline $20^{\circ} \mathrm{C}$ & 217.9 & 874.3 & 720.3 & 786.0 \\
$200^{\circ} \mathrm{C}$ & 206.9 & 804.3 & 656.7 & 731.7 \\
$400^{\circ} \mathrm{C}$ & 193.1 & 728.5 & 608.0 & 666.3 \\
$600^{\circ} \mathrm{C}$ & 141.8 & 570.5 & 487.0 & 639.3 \\
$800^{\circ} \mathrm{C}$ & 81.3 & 190 & 160.0 & 290.0 \\
\hline
\end{tabular}

Values of contractual yield strength at stretching and compression marked in table 1 were used for determination of the temperature coefficient of asymmetry of the elastic region $T_{T}$ expressed with the equation (7). So determined values of the coefficient $T$ in relation to the temperature were presented on the diagram in figure 2.

Numerical simulations where we thermo-mechanically model the structure loads as a rule have a variable temperature in time. Therefore, during numerical calculations the program should have access to the values of the coefficient of asymmetry of the cycle $T$ in any temperature within the range of $20-800^{\circ} \mathrm{C}$. Therefore, instead of using interpolation procedures, a multinomial equation was determined that describes the change of the coefficient ${ }_{T}$ from the temperature in the form of:

$$
\mathcal{\varkappa}_{T}=4,1 \cdot 10^{-9} T^{3}-2,57 \cdot 10^{-6} T^{2}+4 \cdot 10^{-4} T+1,09
$$

Figure 2 presents the graph of the change of the value of coefficient $T$ with temperature, obtained according to the equation (8) with values calculated based on the data from tensile and compression tests.

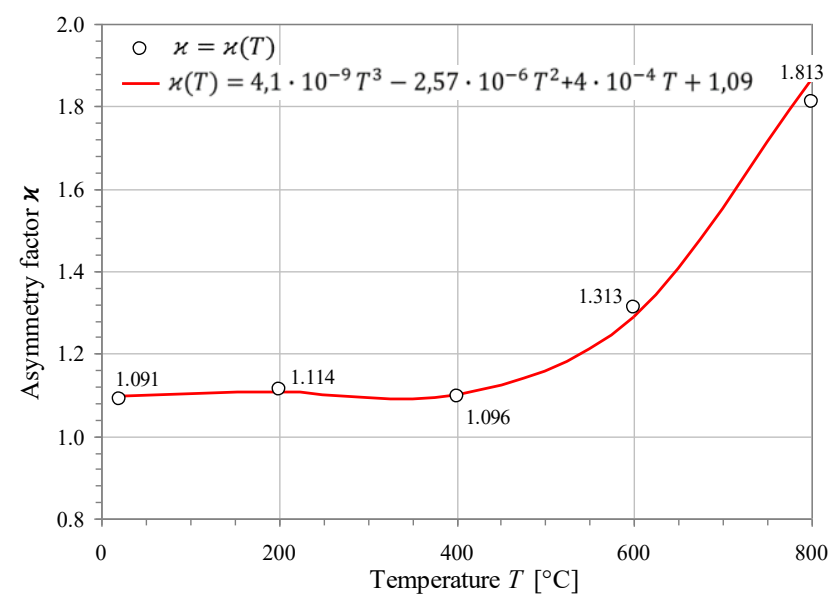

Figure 2. Coefficient of asymmetry of the elastic region $T$ as a function of temperature 
Burzyński’s criterion...

\section{Modified plasticity surfaces}

The plasticity surface as a function of major efforts $\sigma_{1}, \sigma_{2}, \sigma_{3}$, after modification of Burzyński's hypothesis is expressed with a relation

$\sigma_{1}^{2}+\sigma_{2}^{2}+\sigma_{3}^{2}-2 v\left(\sigma_{1} \sigma_{2}+\sigma_{2} \sigma_{3}+\sigma_{3} \sigma_{1}\right)+\left(\mathcal{\varkappa}_{T}-1\right)\left(\sigma_{1}+\sigma_{2}+\sigma_{3}\right) R_{0.2 r}^{T}-\mathcal{\varkappa}_{T} \cdot\left(R_{0.2 r}^{T}\right)^{2}=0$

where:

$v \quad-$ is a plasticity coefficient which Burzyński defined as follows

$$
v=\frac{R_{e t}^{T} R_{e c}^{T}}{2\left(R_{e s}^{T}\right)^{2}}-1
$$

The value $R_{e s}^{T}$ in the relation (10) means the yield strength when twisted. Thus, it is clear that Burzyński included in his hypothesis the difference of properties not only at stretching and compression but also at twisting. Certainly, in the future, the coefficient $v$ should also be revalorised from the temperature. However, due to ongoing studies on determination of the temperature impact on the value of the yield strength at twisting, at this stage of research it was assumed $v=0.5$. Moreover, assuming now this and not any other value of the yield strength was dictated, inter alia, by the fact that Burzyński postulated this value for hard and plastic materials, therefore the relation (3) is determined at the assumption $v=0.5$.

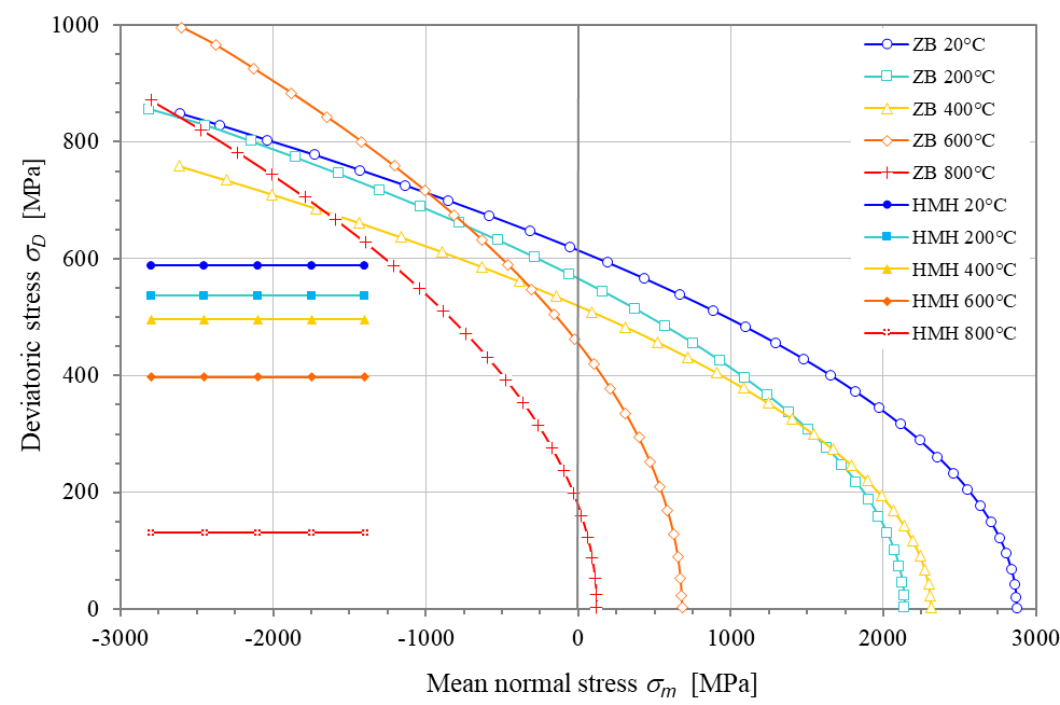

Figure 3. Cross-sections of the plasticity surfaces of Huber-Mises-Hencky's hypotheses and modified Burzyński's with axiator surface for St12T steel 
Using the relation (9) at $v=0.5$ and including the temperature change of the coefficient of the cycle asymmetry and contractual yield strength to stretching (Table 1) the surfaces of plasticity of St $12 \mathrm{~T}$ steel for temperature $20^{\circ} \mathrm{C}, 200^{\circ} \mathrm{C}, 400^{\circ} \mathrm{C}, 600^{\circ} \mathrm{C}, 800^{\circ} \mathrm{C}$ were determined. In case of the modified Burzyński's hypothesis these are paraboloids and for HuberMises-Hencky these are cylinders. For all these surfaces, a longitudinal axis is a hydrostatic axis for which $\sigma_{1}=\sigma_{2}=\sigma_{3}$ takes place and thus it is a perpendicular axis to the deviator surface. Figure 3 presents cross-sections of these surfaces with the axiator surface, i.e. the surface that includes this axis. But, the cross sections of the plasticity surface in Fig. 3 were made by deferring on the horizontal axis the mean stress value $\sigma_{m}$, and on the vertical axis, deviator stress values $\sigma_{D}$ i.e. the value of the projection of the geometrical sum of main stresses vectors of a particular point of the plasticity surface on the deviator surface.

The analysis of the shape of the plasticity surface, whose cross-sections were presented in figure 3, show a strong impact of temperature on the evolution of the surface of the plasticity beginning, in particular within the region of stretches, the so-called region $\left(\sigma_{1}+\sigma_{2}+\sigma_{3}\right)>0$. Particularly s.ignificant seems to be the impact of the value of the asymmetry coefficient $T$ for the temperature of ca. $400^{\circ} \mathrm{C}$. A local minimum is visible here, the result of which is a movement of the front of the plasticity surface for $400^{\circ} \mathrm{C}$ before the front of the surface for $200^{\circ} \mathrm{C}$ (Fig. 3).

\section{Thermo-mechanical simulation of the turbine vane load}

To compare the effort determined with Huber-Mises-Hencky's hypothesis and revalorised Burzyński's hypothesis, numerical simulation of finite elements of the thermo-mechanical load of the turbine vane was performed. The analysis consisted in determination of the effort during heating and cooling of the guide vane embedded without clearance in the direction of $x$ between non-deformable walls determined with digits 1,2 and 3 (Fig. 4A), the movements on the indicated walls were blocked in the $\mathrm{x}$ direction. Heating and cooling of the vane took place on the surface of its blade and, a root and shelf adjusting to its surfaces of (Fig. 4 b). While the cycle of the temperature change in time was presented in figure 5 .

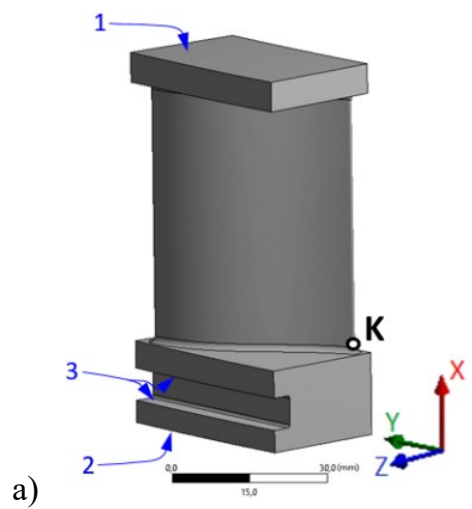

b)

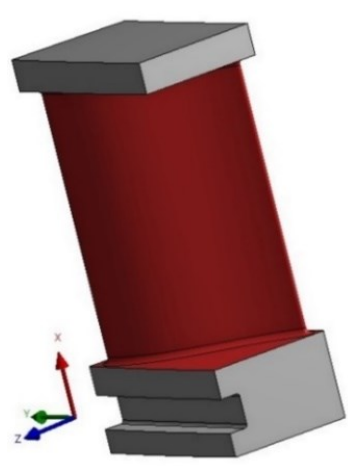

Figure 4. Model of the turbine vane: a) regions where movements are blocked, b) regions where the vane is heated and cooled 


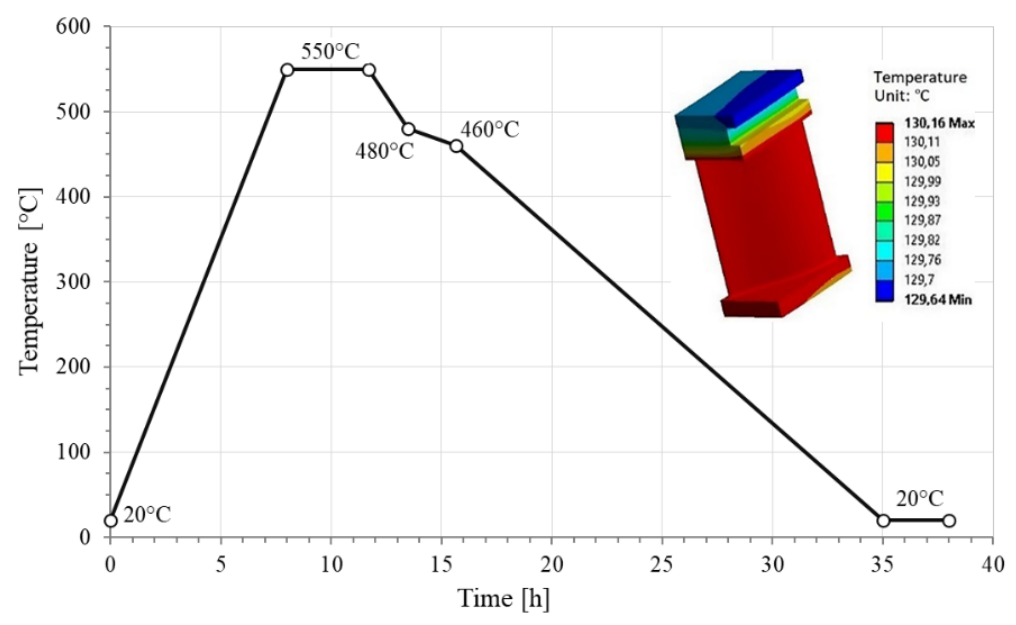

Figure 5. Change of the temperature in the heating and cooling cycle of a vane

Thermo-mechanical analysis with the use of finite elements method was performed. A change of temperature of heating the vane blade was set according to the cycle presented in figure 5. The effect of the analysis that was performed was to determine the vane stress strain based on Huber-Mises- Hencky's hypothesis according to the relations (1) and according to the modified Burzyński's hypothesis according to the relations (3) including the temperature change of the asymmetry coefficient of the cycle expressed with the equation (8) and Young module (Table 1).

Figure 6 presents the state of the vane effort at the temperature of $550^{\circ} \mathrm{C}$ described with HMH's hypothesis (Fig. 6 a) and revalorised Burzyński’s hypothesis (Fig. 6 b).

a)

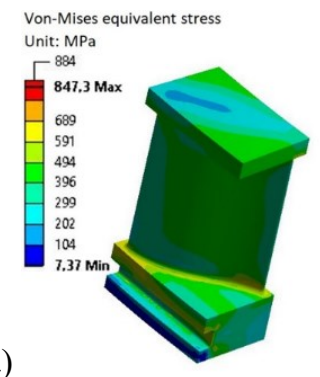

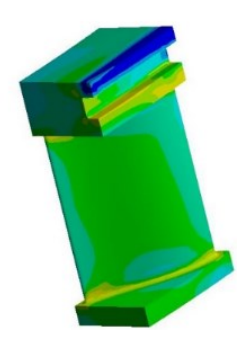

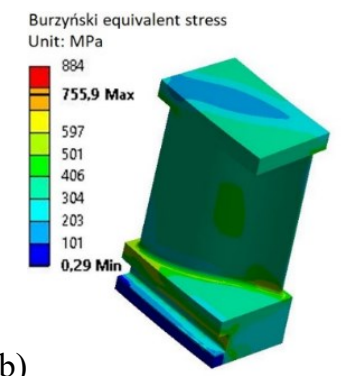

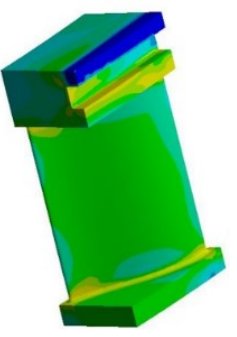

Figure 6. Effort of vane acc. to HMH (a) and Burzyński (b) after its heating to $550{ }^{\circ} \mathrm{C}$

Analogically, figure 7.a and 7.b present the effort of this vane after its cooling to $20^{\circ} \mathrm{C}$ described correspondingly with HMH's and Burzyński's hypotheses. 

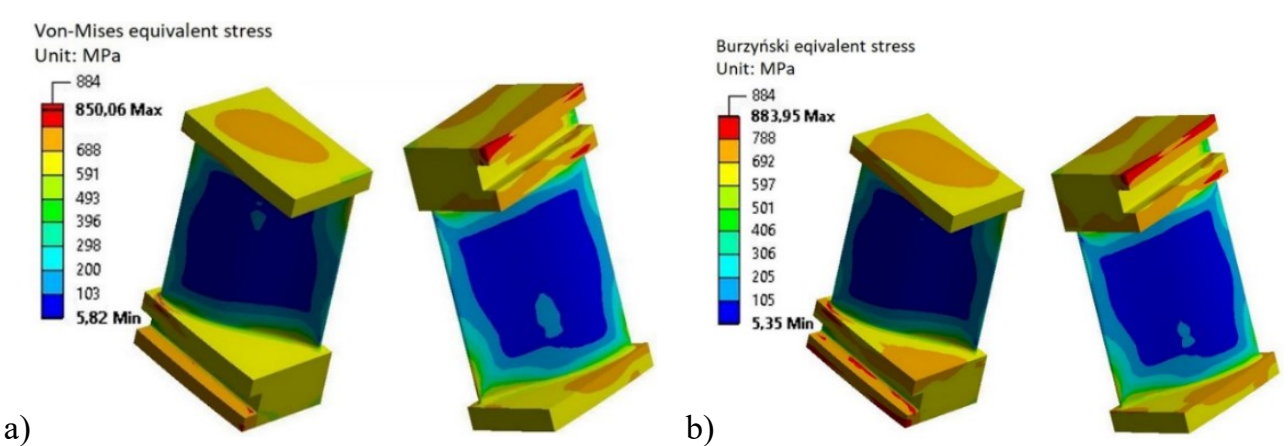

Figure 7. Effort of vane acc. to HMH (a) and Burzyński (b) after its heating to $20{ }^{\circ} \mathrm{C}$

During inspection of damages of such type of vanes, recurrent cracks on the edge of outlfow within the area between a blade and root of the vane were reported. This area was marked with $\mathrm{K}$ in figure $4 \mathrm{a}$.

Moreover, it is assumed that vanes were very closely adjusted during the installation in the turbine body. It was considered whether vane shelves could have stuck in the turbine body during its exploitation. Thus, numerical simulations of the heating-cooling cycle (Fig. 5) including, inter alia, blockings of movement of the surfaces indicated with digits 1,2 and 3 in figure $4 \mathrm{a}$ were performed. A variant of thermo-mechanical load cycle presented in the paper at the indicated manner of blocking of movements was one of many numerically analysed.
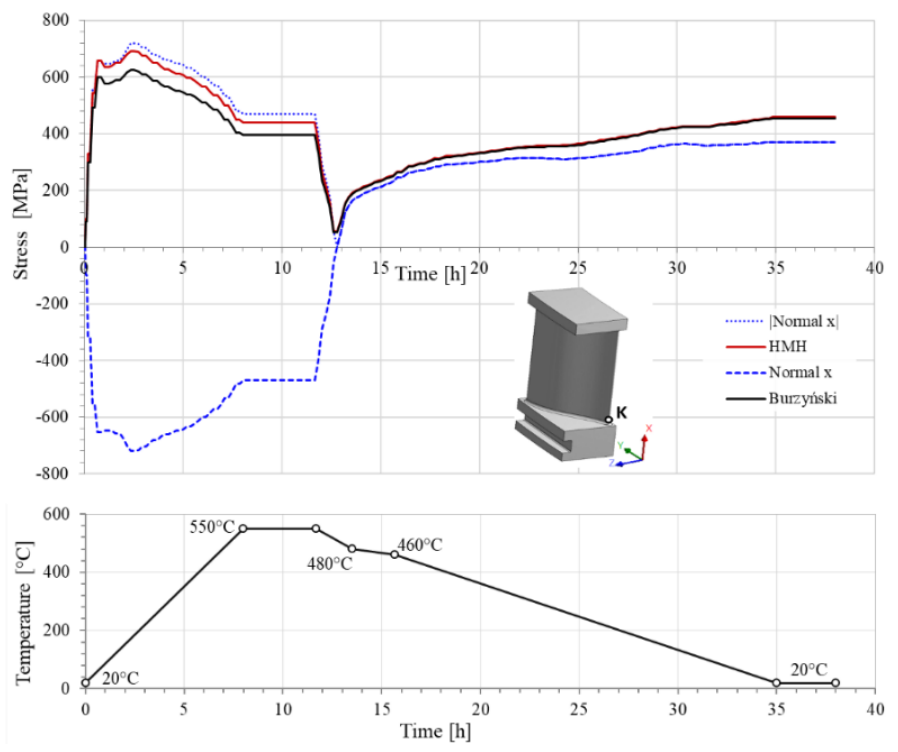

Figure 8. Change of the reduced stresses acc. to HMH and Burzyński in point K (Fig. 4) during the thermo-mechanical cycle of load 
Burzyński’s criterion...

Figure 8 presents for point $\mathrm{K}$ courses of changes in time (and at the same time in the changing temperature): equivalent stresses: acc. to HMH and the modified Burzyński's hypothesis, as well as the course of changes of normal stress in the direction of $\mathrm{x}$ axis.

To easily compare the course of stresses, a mirror reflection towards the time axis of the normal element graph $\sigma_{x}$, stress tensor in point $\mathrm{K}$ was performed. Obviously, a mirror reflection was only made on the area of negative values of this element (Fig. 8). It is easy to notice that in point $\mathrm{K}$, values of the element $\sigma_{x}$ had to considerably prevail over the remaining elements of the stress tensor, which was reflected during comparison of the remaining results obtained from the numerical analysis.

\section{Conclusion}

Revalorised Burzyński's hypothesis presented in the paper enables description of the effort of heat resistant materials, includes a wider scope of strength properties, values of which may change disproportionally towards each other along with the change of temperature.

Evolution of the surface of the beginning of plasticity of St12T steel presented in figure 2 indicates a strong influence of the temperature on the bearing capacity of the material especially in the area of stretches, i.e. for $\left(\sigma_{1}+\sigma_{2}+\sigma_{3}\right)>0$. At the temperatures exceeding $800^{\circ} \mathrm{C}$ one may say that possibilities of effort of this material in the areas of stretches aims to zero.

Thermo-mechanical simulations of the vane load indicate that in point $\mathrm{K}$ of the vane, HMH's reduced stress provides higher values than the one determined according to Burzyński's hypothesis, but only in the moment when in a given area a condition of compression prevails (Fig. 8). In case, when in a given area stretching dominates, both hypotheses provide similar values of the reduced stresses. That does not mean that Burzyński's effort will be always lower or at least equal to the HMH's effort. If the analysis of the vane effort is not limited only to one point, but its whole within the entire thermo-mechanical load cycle, then Burzyński's hypothesis may prove higher effort than HMH. Certainly, the highest effort for the same load state takes place not in the same point but in similar areas of the vane. When comparing the maximum efforts determined acc. to both hypotheses, we see (Fig. 6.a and b) that in case of the vane thermally loaded to $550^{\circ} \mathrm{C}$, equivalent stress $\mathrm{HMH}$ exceeds by 91.4 $\mathrm{MPa}$ Burzyński's stress. On the other hand, after cooling of the vane from $550^{\circ} \mathrm{C}$ to $20^{\circ} \mathrm{C}$, the maximum Burzyński's equivalent stress is higher by 33.9 MPa than the HMH stress (Fig. 7 a. and b).

\section{References}

Banaszkiewicz, M., Dudda, W. (2018). Applicability of notch stress-strain correction methods to lowcycle fatigue life prediction of turbine rotors subjected to thermomechanical loads. Acta Mechanica et Automatica, 12, 179-185.

Banaszkiewicz, M., Dudda, W., Badur, J. (2019). The Effect of Strength Differential on Material Effort and Lifetime of Steam Turbine Rotors Under Thermo-Mechanical Load. Engineering Transactions 67, 167-184.

Banaś, K., Badur, J. (2017). Influence of strength differential effect on material effort of a turbine guide vane based on thermoelastoplastic analysis. Journal of Thermal Stresses, 40, 1368-1385.

Burzyński, W. (2008). Theoretical foundations of the hypotheses of material effort. Engineering Transactions, 56, 269-305. 
Dudda, W. (2007). Numerical modeling of cyclic strengthening and weakening of material. SPIE Proceedings Vol. 6597: Nanodesign, Technology, and Computer Simulations, DOI: 10.1117/12.726762, pp. 65970Z (pages 6).

Dudda, W., Ziółkowski, P.J., Badur, J. (2019). O wytężeniu Burzyńskiego podczas obciążenia termomechanicznego łopatki turbiny. XIV Międzynarodowa Konferencja naukowo-techniczna: Elektrownie Cieplne Eksploatacja-Modernizacje-Remonty, Słok k/Bełchatowa.

Dudda, W., Banaszkiewicz, M., Ziółkowski, P.J. (2019). Validation of a Burzyński plasticity model with hardening - a case of St12T. AIP Conference Proceedings 2077.

Dudda, W. (2019). Influence of High Temperatures on the Mechanical Characteristics of 26H2MF and ST12T STEELS. Materials Science, Vol. 55(3), 435-439.

Dudda, W. (2020). Mechanical Characteristics of 26H2MF and St12T steels under compression AT elevated temperatures. Strength of Materials, Vol. 52, No. 2, 325-328.

Lecomte-Beckers, J., (Ed.) (2002). Materials for Advanced Power Engineering. Schriften des Forschungszentrums Julich, vol. 20, Reihe Energietechnik, Germany.

\section{KRYTERIUM BURZYŃSKIEGO \\ W ANALIZIE STALI ŻAROWYTRZYMALYCH}

Streszczenie. W pracy zaproponowano zrewaloryzowaną hipotezę Burzyńskiego do określania wytężenia elementów konstrukcji w termicznie zmiennych warunkach obciążenia. Wykorzystując proponowaną hipotezę wyznaczono powierzchnie początku plastyczności dla żarowytrzymałej stali St12T. Przeprowadzono dwie symulacje numeryczne termo-mechanicznych obciążeń łopatki turbiny wykonanej ze stali St12T. Efektem wykonanych analiz było określenie stanów wytężenia łopatki wg hipotezy Hubera-Misesa-Hencky'ego oraz wg proponowanej zrewaloryzowanej hipotezy Burzyńskiego.

Słowa kluczowe: hipoteza Burzyńskiego, naprężenie ekwiwalentne, łopatka turbiny 